\section{Revista de Literatura, História e Memória

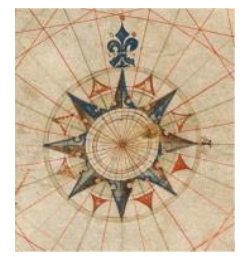 \\ Seção: Pesquisa em Letras no contexto Latino-americano e Literatura, Ensino e Cultura \\ ISSN 1983-1498 \\ VOL. 17 - No 29 - 2021 \\ U N I O E S T E / CA S C A V E L - p. 352-370}

\title{
COSMOGONIA TAPUIA COMO RASTRO IDENTITÁRIO EM XILOGRAVURAS NO ROMANCE D'A PEDRA DO REINO
}

\author{
Ariano Suassuna's romance D'a pedra do reino \\ xylography as an identity trace of tapuia cosmogony
}

\author{
Marcos Paulo Torres Pereira ${ }^{1}$
}

RESUMO: O presente artigo tem por objetivo analisar a constituição do campo simbólico empregado por Ariano Suassuna à ilustração de suas obras, principalmente aquelas que compõem o Romance d'A Pedra do Reino, no que tange à presença de um caráter ameríndio cosmogônico ressignificado pela interpretação mítica cariri que se instaurara em seu discurso, constituído por resíduos de memória e de mentalidades redivivos em rastros significativos que integralizam obras plásticas (eruditas e populares) e sinais rupestres em sua obra literária. Objetiva-se, ainda, debater a forma como esses rastros são constituídos num todo partilhado, distinto de sua origem, em marcador residual de presença de mentalidade ameríndia canibalizada em sua obra literária.

PALAVRAS-CHAVE: Ariano Suassuna; Cosmogonia Ameríndia; Sinais Rupestres; Itacoatiara do Ingá.

\begin{abstract}
This study aims to analyze the constitution of the symbolic sphere Ariano Suassuna uses to illustrate his works, primarily those that compose the novel Romance d'A Pedra do Reino, regarding the presence of an amerindian cosmogonic feature reframed by the cariri mythic interpretation that was established in the author's speech, formed by residues of memory and mentality regenerated in significant traces that fulfill his works with erudite and popular plastic artworks; and rupestrian signs. We also aim to debate how these traces are composed when focusing on the mosaic they fit, considering them as a whole, different from the original amerindian mentality and cannibalized in Ariano Suassuna's literary work.
\end{abstract}

KEYWORDS: Ariano Suassuna; Amerindian Cosmogony; Rupestrian Signs; Itacoatiara do Ingá.

Em entrevista aos Cadernos de Literatura Brasileira, Ariano Suassuna (2000) explicou que enquanto produzia o Romance d'A Pedra do Reino e o Príncipe do Sangue do Vai-e-Volta vira a necessidade do emprego de imagens para complementar e comprovar os relatos de Dom Pedro Dinis Ferreira-Quaderna, personagem principal e narrador da obra, durante o inquérito no qual o personagem se vira envolvido. Todos os acontecimentos engendrados na teia narrativa do romance se viam fortemente atraídos em torno desse inquérito, por isso tais imagens seriam ajuntadas aos autos como provas, seriam empregadas

\footnotetext{
${ }^{1}$ Professor Assistente de Literaturas em Língua Portuguesa pela Universidade Federal do Amapá (UNIFAP). Doutorando em Teoria e História Literária pela Universidade Estadual de Campinas. Coordena o grupo de pesquisa Núcleo de Estudos Pós-coloniais (NePC) e participa como pesquisador do Núcleo de Pesquisas em Estudos Literários (NUPEL), ambos da Universidade Federal do Amapá.
} 
por Quaderna como documentos para compor a peça de seu pedido de absolvição ao processo penal aberto por conta do assassinato de Dom Sebastião Garcia-Barreto, seu padrinho, num crime de quarto fechado, cifrado, enigmático e indecifrável.

Originalmente Suassuna pensara em pedir ao artista plástico Gilvan Samico ${ }^{2}$ que confeccionasse as imagens, pois tinha ciência de que seu estilo, marcado pela gravura e pela xilogravura, casaria facilmente com a Pedra do Reino. Entretanto, se Samico as produzisse, essas sairiam com a assinatura dele, o que quebraria a organicidade do plano de Ariano porque as imagens deveriam ser assinadas por uma das personagens, Taparica Quaderna, gravador popular irmão de Dinis. Suassuna resolvera então que ele mesmo deveria fazer as ilustrações do romance, empregando um estilo que emulava as xilogravuras ${ }^{3}$.

A linguagem das imagens eleita por Ariano ao Romance d'A Pedra do Reino não deve ser compreendida tão somente pela construção identitária de Taparica Quaderna, que por seu ofício trazia a essas gravuras arroladas uma trajetória simbólica identitária do sertão nordestino, pois a xilogravura enquanto arte e técnica "encontrou, no Nordeste brasileiro, o campo propício para se desenvolver, como instrumento de que se valeu a editoração popular e, posteriormente, como reforço de uma memória mítica e expressão estética, que se apropria de várias influências e manifestações" (CARVALHO, 1998, p. 166); porém deve ser também compreendida pela evocação duma outra simbólica, que no Nordeste se abraçou à xilogravura e a tomou de forma esponsal, a literatura de cordel. Para Suassuna (1974b, p. 37), os folhetos de cordel lhe eram bandeira do espírito armorial, porque em si traziam três caminhos à arte, manifestos (I) por sua poesia narrativa, que abriria veredas à literatura, ao cinema e ao teatro; (II) por sua xilogravura, que abriria caminho para a gravura, à pintura, à escultura, à talha, à cerâmica ou à tapeçaria; e, (III) por meio das solfas e ponteados de suas marcas de oralidade, que abririam carreiro para a música.

O que me proponho neste estudo é analisar a constituição do campo simbólico

\footnotetext{
${ }^{2}$ O artista plástico Gilvan Samico fora convidado em 1971 por Ariano Suassuna a fazer parte do Movimento Armorial e de pronto aceitara porque ele vinha se voltando para uma manifestação de cultura popular em suas obras, na busca de uma arte de características brasileiras. Sobre o tema, indico a leitura da dissertação de mestrado O Bestiário Medieval na Obra de Gilvan Samico, de Fábio Fonseca (2011).

${ }^{3}$ Por sua natureza e técnica de impressão, a xilogravura deve ser compreendida como a arte da gravura em madeira, que serviria de chapa matriz às cópias impressas. Emprego o termo "emular" porque Suassuna não gravava a madeira, tão somente reproduzia o estilo de cópias impressas com esta técnica. O gravurista José Lourenço Gonzaga (Apud. CARVALHO, 1998, P. 184) explica a diferença entre desenho e gravura: "a diferença é, porque também, a xilo é o seguinte: você tem que ver, você tem que ter uma visão contrária, né. A xilo é um carimbo, então é a mesma coisa de um carimbo gráfico. Então você tem, a xilo, a diferença é assim, você desenhando, você tá vendo o desenho ali, como ele vai ficar. Já a xilo não, a xilo você tem que cavar e ter a visão contrária, você tá vendo, você tá fazendo aquele trabalho e imaginando ele ao contrário, e vendo a figura como é que vai ficar. Então é essa a diferença e o complicado é isso aí, até no problema de letra, você vai botar um nome, o nome você vai ter que escrever ele voltando, né, não é ao contrário, é ele voltando, que é para quando você botar em cima do papel, ficar certo".
} 
empregado pelo autor à ilustração de suas obras, principalmente aquelas que compõem o Romance d'A Pedra do Reino, no que tange à presença de um caráter ameríndio cosmogônico ressignificado pela interpretação mítica cariri que se instaurara em seu discurso, constituído por resíduos de memória e de mentalidades redivivos em rastros significativos que integralizam obras plásticas (eruditas e populares) e sinais rupestres com seu texto literário cristalizado em performance ${ }^{4}$.

"A enunciação da palavra ganha em si mesma valor de ato simbólico" (ZUMTHOR, 1997, p. 15). Entretanto, o valor do ato simbólico não se restringe apenas à enunciação da palavra, insisto, engloba toda a ação performática como fato poético, pelas circunstâncias que lhe são ulteriores. Ainda na entrevista aos Cadernos..., quando questionado a respeito do diálogo entre as artes plásticas e seu texto, Suassuna (2000, p. 30) explica que a obra plástica viria da literatura e que "é das imagens da literatura que surgem as ilustrações, e não o contrário". Idelette Muzart Fonseca dos Santos (2009, p. 207) atesta que a "ilustração suassuniana elabora-se a partir da gravura popular num jogo em que texto e imagem vão se construindo reciprocamente, numa troca permanente de referências e reflexos", fazendo com que a integração entre ambos possa agir de forma a tornar "a obra plena, de sentidos, de imagens, de palavras" (p. 206).

Após esse exercício de ilustração de sua obra, Suassuna aprofundara-se no trabalho com gravuras e chegara às iluminogravuras ${ }^{5}$ (SUASSUNA, 2000, p. 29-30), composições poéticas sincréticas de feição intersemiótica que a um só tempo empregam ilustração e palavra à manifestação literária. No documentário O sertão mundo de Suassuna, de Douglas Machado (2003), o autor explica o processo de confecção destas, que se caracterizava em órbitas que, a priori, seriam distintas dado o caminho manufatureiro empregado: a literatura e o artesanato... Ariano Suassuna compreendia a folha como uma tela cuja "arquitetura" evocaria uma simbólica sob o qual se combinam o sagrado e o profano; o erudito e o popular; o imagético colonial e a voz decolonial; o branco, o negro e o ameríndio; o antigo e o novo ${ }^{6}$.

$\mathrm{O}$ autor tomava de sua tela (folhas de papel cartão) compunha um leiaute, escrevia o

\footnotetext{
${ }^{4} \mathrm{O}$ conceito de performance que sigo se deve a Paul Zumthor, que a define como "a ação complexa pela qual a mensagem poética é simultaneamente, aqui e agora, transmitida e percebida". Como inter-relação, a performance necessita de mecanismos que se adéquem à mensagem e às necessidades dos ouvintes a fim de que possam performatizar a apresentação, pois "nada teria sido transmitido nem recebido, nenhuma transferência se teria eficazmente operado sem a intervenção e a colaboração, sem a contribuição sensorial própria da voz e do corpo" (ZUMTHOR, 1993, p. 71).

5 "Foi somente depois desta experiência, bem-sucedida, que o autor começou a dividir seu tempo de criação literária com trabalhos de desenhos, pintura, programação visual e tapeçaria" (NEWTON JÚNIOR, 1999, p. 121).

${ }^{6}$ Suassuna afirma no documentário que procurara "fundir a iluminura medieval com a gravura popular nordestina e com os processos modernos de gravar pela luz" (MACHADO, 2003).
} 
texto à mão e desenhava as imagens com tinta nanquim num conjunto que serviria de matriz para as cópias que seriam produzidas através de offset. Terminado o processo, Ariano aplicava-lhes cor em cada uma das cópias, em tinta gauche ou tinta a óleo ${ }^{7}$. Dois álbuns foram produzidos seguindo essa técnica, Dez sonetos com Mote Alheio (1980) e Sonetos de Albano Cervonegro (1985), cada um contendo dez iluminogravuras dispostas em pranchas soltas e acondicionadas em uma caixa de madeira.

No mesmo documentário de Douglas Machado, Carlos Newton Júnior analisou uma dessas iluminogravuras, "Abertura - 'sob pele de ovelha",, explicando o influxo de referências e influências adotadas pelo autor, apontando a forma de reorganização e de ressignificação articulada de elementos castanhos, residuais da cultura popular e da cosmogonia ameríndia, na obra de Suassuna:

você percebe aqui no título o alfabeto armorial ou o alfabeto sertanejo, feitos a partir dos ferros de marcar bois. Você vai perceber que essa ilustração é toda baseada no universo pictórico da pré-história brasileira, alguns desses desenhos são identificáveis... esses dois por exemplo estão na pedra do Ingá, este que lembra uma espécie de cacto e este que lembra um candelabro... então você tem sois, luas, frutos, estrelas (...). (NEWTON JÚNIOR apud. MACHADO, 2003).

A iluminogravura analisada se encontra entre aquelas que compõem o álbum Sonetos de Albano Cervonegro (1985), que apresentarei a seguir (Figura 1). Os dois desenhos apontadas por Newton Júnior como oriundos de sinais rupestres da pedra do Ingá são, em várias oportunidades, retomados por Ariano e faziam parte de um conjunto de 3 que o autor denominou de Candelabros, o da Beleza, do Bem e da Verdade, porque representariam a tríplice face de Deus, conforme explicou ancorado em Platão, durante entrevista concedida ao Programa Metrópolis em 28/12/2007 por ocasião de exposição em sua homenagem no Sesc/RJ, Ariano Suassuna, o "decifrador de brasilidades”. Nessa entrevista salientou ainda a importância da pedra do Ingá: “essa pedra está na região agreste da Paraíba e muitas dessas formas eu adoto na minha literatura e no meu desenho", o que seria muito fácil comprovar com a Figura 2, retirada de Romance de Dom Pantero no Palco dos Pecadores (2017). O primeiro desenho deste conjunto de candelabros, o Candelabro da Beleza, fora escolhido por Ariano para fechar suas explanações acerca do caráter heráldico dos ferros de marcar gado

\footnotetext{
7 Ângela Vaz Leão explicou o processo de confecção adotado por Ariano Suassuna em entrevista ao Programa Extra-classe, publicado em 03/10/2014. No artigo “'A Tigre Negra': uma iluminogravura de Ariano Suassuna”, complementou: "a tiragem reduzida de apenas cinquenta exemplares, com rara reprodução posterior de uma ou outra prancha, a pedidos, faz da obra, hoje, uma raridade bibliográfica" (LEÃO, 2003, p. 14).
} 
adotados no sertão nordestino brasileiro, especificamente aqueles do Cariri, conforme se pode observar na Figura 3.

Figura 1: Abertura - "sob pele de ovelha"

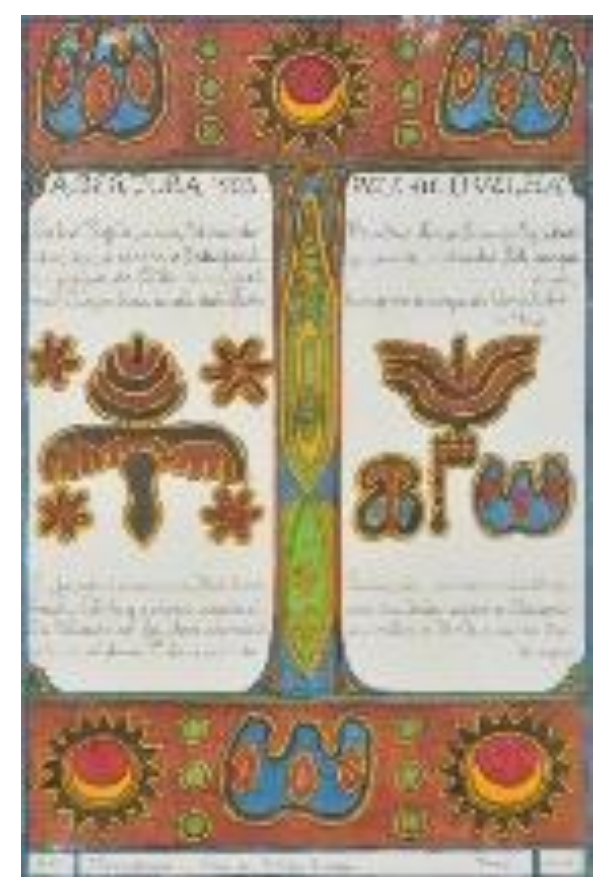

Fonte: Cadernos de Literatura Brasileira, p. 90, 2000.

Figura 2: Em ordem, os Candelabros da Beleza, do Bem e da Verdade
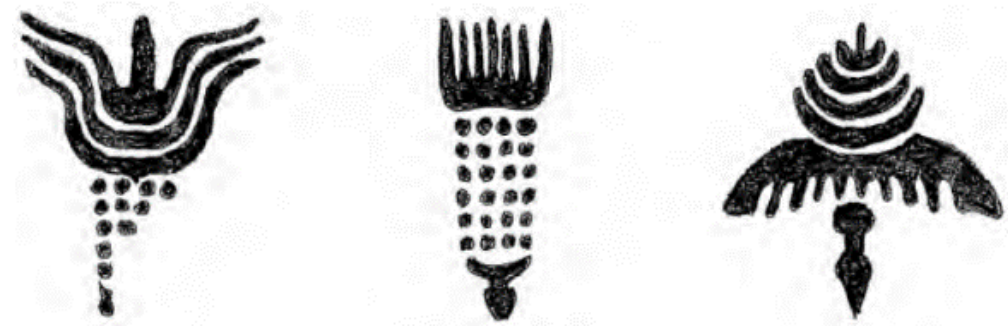

Fonte: SUASSUNA, 2017, p. 23. 
Figura 3: Letras "x", "y" e "z" do alfabeto sertanejo, ou armorial, e o Candelabro da Beleza

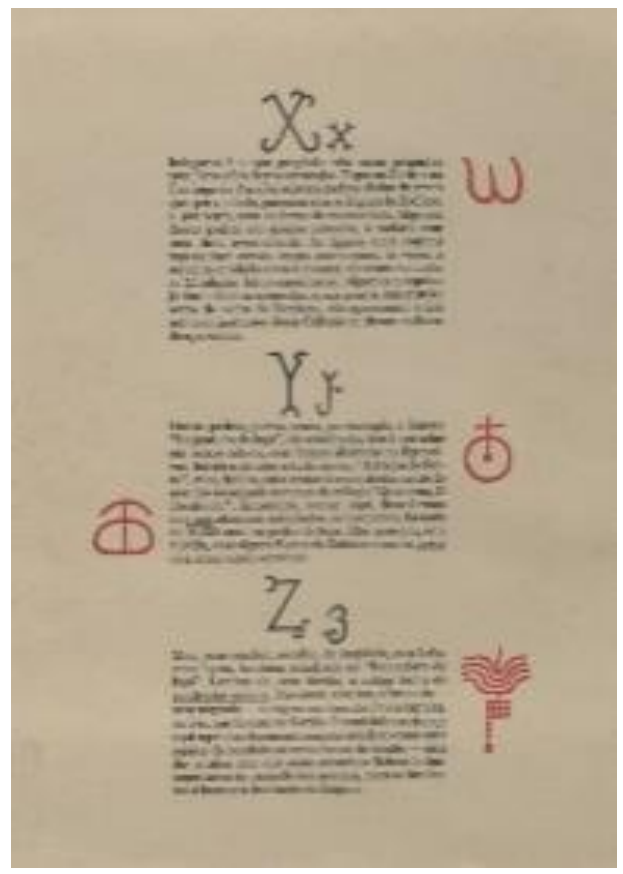

Fonte: SUASSUNA, 1974a, p. 17.

As imagens empregadas por Ariano no conjunto de sua obra vão além do simples caráter decorativo, à medida que ressignificam a iconografia de artefatos da Itaquatiara do Ingá ${ }^{8}$ num repositório simbólico da qual se origina a existência da expressão estética por ele adotada à manifestação de um dos substratos do espírito castanho - a presença e permanência ameríndia - que, conforme defendera em sua tese de livre docência, caracterizaria aquilo que denominara de "civilização do couro", composta por aqueles pertencentes à "Onça Castanha dos povos da Rainha do Meio-Dia"'.

O referencial não fora adotado por Ariano somente no campo religioso, mas também político e histórico: o autor explica seu significado a fim de frisar a relação entre os judeus e o tempo como parâmetro, diferenciando o tempo determinado pela história daquele tempo e

\footnotetext{
8 "Itaquatiara" se origina de "itacoatiara", vocábulo de origem indígena que significa gravura, inscrição rupestre ou pintura em rochas, em paredes de cavernas etc. Do itá: pedra; e coatiara: pintado, escrito, gravado, esculpido.

${ }^{9}$ A expressão Onça Castanha é empregada por Suassuna como referencial metafórico ao povo brasileiro, formado por hibridações e mestiçagens geradoras de uma civilização cuja cor da pele se tornara adusta, semelhante àquela da Onça. A invocação metafórica da expressão Rainha do Meio-Dia, por sua vez, se constitui numa órbita religiosa, contudo não relegada somente a ela, porque ressignificaria caracteres de tempo, identidade e de memória.

Em A Onça castanha e a Ilha Brasil (1976), Ariano aponta que a Rainha de Sabá seria a Rainha do Meio-Dia, seguindo a tradução do texto bíblico de Mateus: 12, 41-42 feita pelo Padre Antônio Pereira de Figueiredo, e que empregara o referencial para "significar simbolicamente todas as raças escuras situadas ao sul em torno do Equador" (SUASSUNA, 1976, p. 20), tornando-se, em sua visão estética, o símbolo central dos povos castanhos, aqueles que chamou no prefácio da Farsa da Boa Preguiça, de "povos morenos e magros do mundo". Maria Thereza Didier, em Emblemas da sagração armorial, escreveu sobre o tema: "sob o olhar de Ariano, o sertão tem o significado de fascinação, pela possibilidade de gestar a beleza genuinamente nacional; no ser castanho, o escritor encontra o subterrâneo que o armorial tenta revelar" (DIDIER, 2000, p. 156).
} 
espaço superior, supratemporal e permanente, "assim tornado por causa de seu sentido transcendente" (SUASSUNA, 1976, p. 19), porque mais importante do que a noção exata de um acontecimento dito histórico, o encontro da Rainha de Sabá com Salomão, encontra-se o relato que humaniza o tempo narrado, que lhe atribui um sentido maior, transcendente, porque captura a manifestação simbólica do tempo.

Seguindo Zumthor (1993, p. 252), aponto ao entendimento de que a obra literária se relaciona com o tempo de duas maneiras: a primeira, relativa ao próprio ato de enunciação, abarcando o tempo necessário ao desempenho do texto; a segunda, por sua integração na duração social, condicionado aos aspectos sócio históricos na amplitude identitária na qual se insere. Essa duração da performance, que Zumthor denomina de tempo integrado, "às vezes, (...) situa-se num ponto determinado", quando se trata de integração na duração social: de algum ciclo cósmico (canções que marcam o início de um período de colheita e canções de solstício são exemplos), de ciclo da existência humana (a oração das carpideiras intercaladas com músicas litúrgicas em ritos fúnebres, por exemplo), de um ciclo ritual (os autos litúrgicos são expoentes) e de duração social ("medindo acontecimentos, públicos ou privados, recorrentes mas de frequências imprevisíveis: encontro amoroso, combate, vitória; ou mais especificamente tal festa, tal acontecimento político" (ZUMTHOR, 1993, p. 253).

Nesses termos é que leio, também apoiado pelos escritos de Paul Ricoeur (1994), esse campo simbólico ameríndio adotado por Suassuna: alijado do tempo determinado pela história, daí as lacunas etnográficas de seu discurso sobre o tema, porém ancorado em um tempo e em um espaço superior de uma história humanizada pelo significado que fora dado à iconografia do Ingá na narratividade de sua obra, constituída por um fundo cosmológico que abarca a ontologia ameríndia de forma perspectivista como um todo significativo. A pedra do Ingá, assim, torna-se para Ariano um marco que alude a relação do homem com o passado, cuja significação histórica e existencial aponta a uma existência paradoxalmente dialética entre a presença (a memória dos povos demarcada) e a ausência (da linguagem que abarca o sentido primeiro do registro), gerando o rastro $^{10}$ dessa simbólica armorial numa tríplice

\footnotetext{
10 Aqui me permito uma livre associação aos escritos de Derrida (2008), que propõe o termo rastro para substituir aquilo que Saussure denominara como signo, como operador da diferença (um signo só adquire sentido quando confrontado a outro signo), de ordem binária e metafísica entre o significante e o significado. Para Derrida, quebranta-se a ideia de origem da língua, quando a diferença traz a concepção não somente de si do signo, mas daquele outro signo que não é, que fora confrontado, porquanto um vir-a-ser instituído, um devir, balizado num jogo de remetimentos, de resíduos culturais e literários, de rastros que não se deixam apropriar, porque são sinais de uma presença que não mais está presente, mas sentida; de uma existência que se demarcaria, porém que não se corporifica, os vestígios, as marcas deixadas por uma ação ou por uma passagem... marcadores de significantes a significantes que matizam a linguagem como um jogo cujas regras se estabelecem durante o próprio por jogadores que sentem a necessidade e o desejo do jogar: "toda língua em geral brota assim que o desejo apaixonado excede a necessidade física, assim que se desperta a imaginação que desperta a piedade e dá
} 
mimeses na qual o símbolo é prefigurado (compreendido como marco ameríndio cariri), não trabalhado pela linguagem, porém reconhecido como marco; configurado no agenciamento de referências à tessitura narrativa de sua obra; e refigurado no ato de leitura, que manifesta significações identitárias à simbólica armorial e à simbólica ameríndia cariri, através do diálogo entre o mundo do texto e o mundo do leitor.

Falando sobre as itaquatiaras sertanejas, Suassuna afirma que no Cariri e na Caatinga da Paraíba "existem pedras cheias de sinais que, por um lado parecem os Signos do Zodíaco, e, por outro, com os ferros de marcar bois. (...) As figuras mais comuns representam cervos, onças, assim como, às vezes, a serpente enrolada sobre si mesma, tão comum a todas as Mitologias latino-americanas" (SUASSUNA, 1974a, p. 17 - grifo do autor), apontando sinais rupestres comuns não somente à pedra do Ingá, mas a outros sítios arqueológicos presentes na região. Este trecho, no entanto, vai além do simples apontamento, porque busca nesses sinais encontrar significados semelhantes a outros pertencentes a simbólicas distintas, tais como o Zodíaco e aos ferros de marcar gado empregados no Cariri, num só repositório significativo. A exemplo disto, o exercício de ressignifição dos sinais rupestres colhidos por Suassuna na itaquatiara do Ingá no ferro de marcar gado utilizado no assassínio por degola do padrinho de Quaderna, Dom Sebastião Garcia-Barreto, n'A Pedra do Reino.

Durante o inquérito, o Corregedor pedira a Quaderna detalhes sobre esse fatídico acontecimento de crime de quarto fechado, a fim de tentar encontrar pistas à sua solução, tentando entender como o quarto se fechara, quais as entradas que este poderia ter, o que eram as seteiras que o ambiente possuía e se estas não poderiam ter sido utilizadas pelo(s) assassino(s). Daí surge um dos elementos mais emblemáticos do crime, que transcrevo a seguir:

é que, na espádua esquerda de Dom Pedro Sebastião, tinham ferrado, a fogo, um ferro desconhecido e que não é nenhum dos ferros familiares de ferrar boi do Sertão da Paraíba! Eu sei, porque no nosso "Instituto Genealógico e Histórico do Sertão do Cariri" temos um arquivo e registro desses ferros, arquivo que eu organizei por sugestão do Doutor Pedro Gouveia!

- Você ainda se lembra como era o ferro?

- Me lembro como se fosse hoje, Excelência! Era uma espécie de lua, ou melhor, para ser mais fiel à nobre Arte da Heráldica, um crescente, com as pontas viradas para cima e encimado por uma cruz.

movimento à cadeia suplementar" (Derrida, 2008, p. 265), por isso seu advento é o advento do jogo, por isso "o rastro é verdadeiramente a origem absoluta do sentido em geral. O que vem a afirmar mais uma vez, que não há origem absoluta do sentido em geral. O rastro é a différance que abre o aparecer e a significação. Articulando o vivo sobre o não-vivo em geral, origem de toda repetição, origem da idealidade, ele não é mais ideal que real, não mais inteligível que sensível, não mais uma significação transparente que uma energia opaca e nenhum conceito da metafísica pode descrevê-lo" (DERRIDA, 2008, p.80). 
- A marca do ferro na espádua de seu Padrinho era recente?

- A queimadura era recentíssima! Quando a gente entrou na torre, sentia-se ainda a catinga meio fumaçada e polvorenta de carne de bicho ferrada!

- E não havia nenhum sinal do fogo onde esquentaram o ferro?

- Nenhum, Excelência! Eu não já expliquei que no aposento elevado da torre da capela não havia nada, a não ser o sino? (SUASSUNA, 2014, p. 365).

O ferro que marcara a espádua de Dom Sebastião trazia semelhanças com dois sinais rupestres recolhidos na pedra do Ingá, que foram apresentados por Ariano em Ferros do Cariri: "avanço, aqui, duas formas de sinais abstratos, entalhados, ao que parece, há mais de 10.000 anos, na pedra do Ingá. Elas parecem, sem dúvida, com Signos do Zodíaco e com os ferros de marcar o gado sertanejo" (SUASSUNA, 1974a, p. 17 - grifo do autor). Conforme se pode apreender na figura a seguir, os referidos sinais podem ser lidos como protoimagens àquela empregada no ferro. Seguindo os postulados de Sperber (2009), a necessidade de efabular faria com que Ariano capturasse tais sinais para lhes atribuir sentido através da significação, enquanto o imaginário os inter-relacionaria aos elementos da narrativa.

Figura 4: Em ordem, duas figuras rupestres recolhidas da itaquatiara do Ingá e a marca do ferro que ferira o corpo de Dom Sebastião Garcia- Barreto
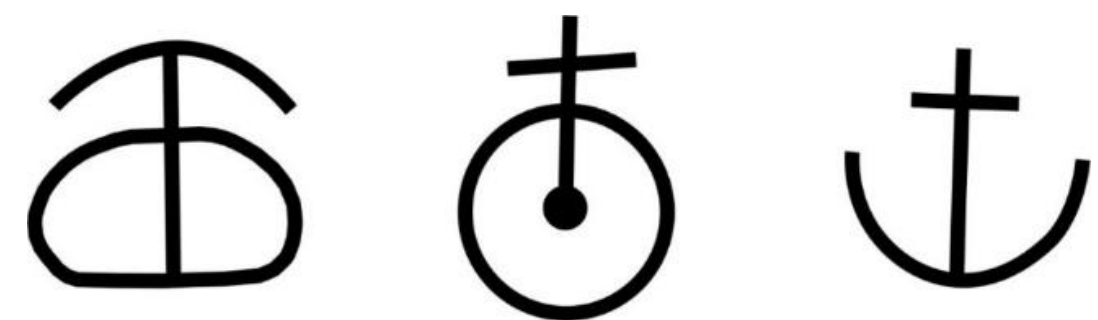

Fonte: SUASSUNA, 1974a, p. 17; p. 10.

O leitor que tomasse somente a descrição que Quaderna fizera do ferro reconheceria o sinal identitário deste mediante um exercício de prefiguração. O leitor que, por sua vez, tivesse ciência da simbólica heráldica e armorial relacionaria essa marca com o contexto deste, através da configuração do símbolo no texto; contudo, o leitor que trouxesse à leitura da Pedra do Reino o conhecimento de mundo sobre a itaquatiara do Ingá poderia, além das interpretações citadas, inter-relacionar a obra à cosmogonia cariri e compreender a permanência residual do espírito ameríndio na refiguração dos símbolos n'A Pedra do Reino.

Dom Pantero, um dos narradores do Romance de Dom Pantero no Palco dos Pecadores, de Ariano Suassuna (2017), retoma a pedra do Ingá para análise, enaltecendo sua origem mítica e castanha, seu caráter cifrado, mágico e armorial: 
Jaguapardo - o Lagarto, Jaguar e Leopardo-castanho, com malhas estreladas em sua áspera pele, entalhadas, há milhares de anos, por uma Tribo ancestral desconhecida; eram belas e terríveis marcas, cortadas em baixo-relevo, a modo de ferimentos e cicatrizes que transformavam o exterior castanho do Lajedo ali deitado num imóvel Planetário, num misterioso Planisfério-cosmogônico petrificado.

Vista de longe, a Itaquatiara parecia um torso deitado de Mulher, com o corpo marcado pelas tatuagens insculpidas em sua grossa pele. Mais de perto, semelhava um gigantesco Cachalote, um Monstro marinho e préhistórico que, aportando ali na época em que o Sertão era um escuro fundo de Mar, encalhara e, secadas as águas pela passagem do Tempo, fora petrificado em granito. Milhares de anos depois, tivera sua áspera crosta alisada e insculpida pela mão dos homens e mulheres da Tribo, nossos antepassados Cariris (instruídos pelo Moço-Dono-do-Fogo, pela Moça-Retrato-da-Lua e principalmente pelo Filho-do-Sol). (SUASSUNA, 2017, p. 294).

Se Lewis Carroll apresentou seu Jaguadarte em Alice Através do Espelho, Dom Pantero apresentou seu Jaguapardo como um rastro de permanência cosmogônica, como marco residual de uma mentalidade que se cristalizava em pedra e em relato no imaginário da obra de Suassuna... Se Carroll tomou de neologismos à confecção de seu poema, Suassuna apoderara-se dos cifrados remanescentes do Ingá como rastro à mitologia cariri das divindades tapuias, fincada desde o Romance d'A Pedra do Reino.

A referência à Pedra do Ingá em Dom Pantero e no Romance d'A Pedra do Reino não são, contudo, os únicos casos da permanência cosmogônica ameríndia que aparecem na obra de Ariano. Se em suas iluminogravuras os sinais rupestres evocavam o rastro que levaria para Ingá, em História do Rei Degolado e em As Infâncias de Quaderna, obras que dariam continuidade ao inquérito instaurado na Pedra do Reino, o mesmo acontecera, como se pode atestar no relato da árvore genealógica de Quaderna, que afirmava descender pelo lado tapuia da família “do Cacique Suaçuq-Puna, O Veado Negro, Rei Cariri cujos domínios cobriam toda a bacia do Rio Taperoá-Paraíba, desde Ingá do Bacamarte até Teixeira e Monteiro" (SUASSUNA, 1976, p. 5), e nos relatos concernentes aos anfiteatros de pedra, donde se descortinara a Dinis Quaderna a narrativa da Mitologia Tapuio-Cariri:

No centro do enorme anfiteatro, havia, isolada, uma grande pedra esculpida. Entre suas figuras, havia em baixo-relevo, uma espécie de Lua, Ligada a um Sol de cabeleira flamejante através de uma flecha. Em torno, havia várias pedras menores disseminadas, das quais doze eram também entalhadas com vários signos e figuras Cariris - coisa que só fui entender claramente depois, quando o Professor Clemente foi levado lá por mim e me explicou a Mitologia Tapuio-Cariri.

(...)

É que, aqui na Paraíba, existem vários desses locais, com pedras pintadas e 
esculpidas pela raça Cariri, Sr. Corregedor! Em Ingá existe, como já lhe disse, a famosa Itaquatiara. $\mathrm{Na}$ serra do Teixeira existe uma espécie de anfiteatro - ou de teatro, mesmo - de cujo altar principal, a Pedra do Caboclo, que é cheia de sinais pintados, um sussurro é ouvido em todo o semicírculo de pedra chã, de cerca de trezentos metros de diâmetro.

(...)

Mas como eu vinha dizendo, Sr. Corregedor: foi somente depois de ter ouvido as explicações de Clemente que eu entendi o que significavam a pedra-central e aquelas outras dozes que a circundavam. A grande pedracentral era uma ara dedicada à Divindade primordial dos Tapuias, MaretQmanian, nome que eles davam ao JAGUARAIAR. As outras doze era voltadas a Mair-Ataq, Sinareq, Arecout, Munhang, Mair-Munhang, ao Aroexeba-Munhang, à Igpupiara, a Anhang, a Tupang, a Puqxi, a MairPuqxi, ao Aroexeba-Negro, enfim, a todos os Deuses-machos, Divindadesfêmeas, animais sagrados, metamorfoses e outras coisas que tinham dado origem ao mundo e ao homem naquela Terra-desértica, pedregosa e sagrada do Sertão do Brasil. (SUASSUNA, 1976, p. D-3).

Outra imagem empregada por Ariano n'A Pedra do Reino segue esse rastro de permanência da cosmogonia ameríndia aos grifos que compõem os mistérios do inquérito no qual Quaderna se vira envolvido. A imagem exibiria pinturas rupestres que se encontravam na Gruta do Olho-d'Água do Pedro, “onde recentemente tinham se descoberto 'várias inscrições petrográficas e desenhos feitos pelos Tapuias nas paredes de pedra" e que o narrador se apressara em nomear de "Dama de Paus Tapuia", ressignificando seu sentido àquele imaginário castanho sobre o qual orbitara suas crenças.

Figura 5: Dama de Paus Tapuia

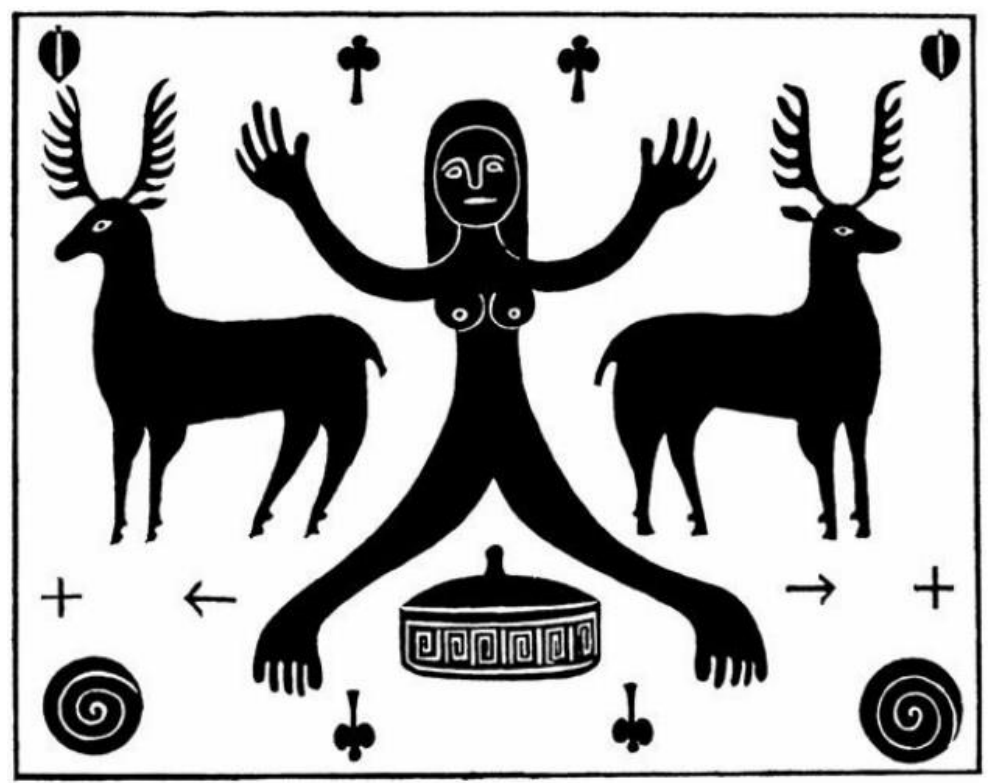

Fonte: SUASSUNA, 2014, p. 202.

Quaderna confessa ao Corregedor que a imagem encontrada na gruta despertara 
caloroso embate entre seus companheiros, Clemente e Samuel, como sempre ocorria entre eles ante as diferentes perspectivas assumidas por ambos em relação ao mundo (o primeiro, de esquerda, negro, decolonial; o segundo, de direita, branco, colonial):

Naquele dia, quando chegamos à Gruta, houve forte discussão entre os dois, diante das pinturas dos Tapuias. Usavam-se, nelas, duas cores, o negro e o vermelho, que, sobre o amarelado da pedra, davam um total de três, o que não era comum. Samuel irritou-se diante daquelas pinturas "grosseiras, desproporcionadas e pueris". Clemente sustentava, ao contrário, que aquele sim, deveria ser "o ponto de partida oncístico e popular da Arte brasileira". Mostrou-me uma moça, com as pernas e os braços abertos, parecendo uma Jia, ladeada por dois veados e cercada de garatujas. Destas, quatro me pareceram logo as marcas do naipe "Paus", e duas as de "Espadas". Clemente refugou isso e explicou:

- Essas figuras, Quaderna, são símbolos sexuais masculinos e femininos, são símbolos fálicos! O resto, são espirais, setas e essa espécie de cruz torta, sinais cabalísticos muito comuns na Arte tapuia!

- Pois quando eu chegar na rua, vou pedir a meu irmão para fazer uma cópia dessa "Dama de Paus Tapuia"! - disse eu. - Depois, caso a Dama tapuia com o Rei de Ouro ibérico, e vou ver se o casamento é mais fecundo do que o primeiro que ele teve com a princesa da Casa de Saboia!

Se de um lado estava o negro e do outro o branco, no meio desses o narrador se apresentava como a epítome do castanho, reconhecidamente mestiço. Desde a morte de seu Padrinho, o genuíno herdeiro do Trono do Cariri que acumulava "com os outros de Gênio da Raça Brasileira, Rei do Quinto Império do Sertão, Imperador do Divino, do Sete-Estrelo do Escorpião, Profeta e Sumo-Pontífice da Igreja Católico-sertaneja” (SUASSUNA, 2014, p. 534), o herdeiro que se aproveitara de ambas as perspectivas para traçar uma nova, uma terceira que abarcaria aquilo que melhor fosse encontrado nas duas anteriores para, residualisticamente, antropofagicamente ${ }^{11}$, matizar o mito cariri que orbitaria suas ideais de conquista, de mistério e safadeza.

A Gruta do Olho-d'Água do Pedro encontrava-se no lajedo que Quaderna definira como seu Lajedo Sagrado. Durante o Folheto LXXI, "O Caso do Jaguar Sarnento", o Corregedor inquerira ao narrador sobre qual o seu papel no atentado que ocorrera em Taperoá, um dos ditos acontecimentos engendrados na teia narrativa a que me referi no início deste estudo, e por que ele se encontrava no lajedo exatamente no dia em que esse atentado se dera, já que de lá, segundo carta denunciante, partira o disparo. O inquerido tergiversa apelando para os dogmas da religião que fundara, seu Catolicismo-sertanejo, e aos grifos e cifrados de

11 “A Antropofagia, ou mais abstratamente, a relação de devoração, não é apenas uma prática cultural específica, mas informa de modo geral a cosmologia (a Weltanschauung, como diria Oswald fazendo uso do vocabulário da época) de muitos povos ameríndios". (NODARI, 2019, p. 21) 
sua narrativa:

- Sr. Corregedor, conhecendo, como conheço, os Enigmas e os fins ocultos de tudo o que se passou nessa história; conhecendo os fios secretos que ligavam todos os acontecimentos; conhecendo, ainda, o papel que tinha e tenho a desempenhar na "Guerra do Reino" e na "Demanda Novelosa do Reino do Sertão", só posso atribuir, mesmo, minha ausência da Vila naquele instante a uma disposição oculta da Providência Divina!

O amparo dos desígnios e da providência Divina evocados por Quaderna traziam ao seu discurso um ar nobiliárquico adquirido não pela humildade do penitente, mas pelo orgulho litúrgico que instrumentaliza os ritos de sua fé, pois sua alegação quanto à presença no lajedo não se dera pelo acaso ou plano seu, e sim porque urgiria a um ente maior que Dinis Quaderna lá estivesse naquela fatídica hora. Na Mitologia Tapuio-Cariri na qual se fiava e concebia, o ente era a Onça-Parda, a Fera estranha "em cujo dorso habita a raça piolhosa dos homens" (SUASSUNA, 2014, p. 31), que lhe aparecera em uma visagem de espelho numa encruzilhada, quando ainda era seminarista e se encontrava de viagem de Taperoá para o Seminário da Paraíba. Dinis Quaderna explica ao Corregedor que a visagem lhe fizera entender o papel da humanidade no teatro da vida, de sua condição piolhosa de uma "vidaerrante, extraviada e perdida por tudo quanto foi caminho e descaminho" do sertão, o que lhe despertara "questão, ao mesmo tempo, de fé, de sangue, de ciência, de estro e de planeta!", que culminara com a fundação de sua fé, o Catolicismo-sertanejo ${ }^{12}$.

A onça era tema caro a Quaderna assim como também o era para Ariano Suassuna. Em “O Cariri em Armadura de Couro" (PEREIRA, 2020, p. 367), expliquei esse resgate totêmico, perspectivista e simbólico como um devir-onça da qual se contagiara o autor e da qual lhe despertaria um universo castanho e mítico de uma simbólica cariri geradora de referências metafóricas à esfera do agir humano, ressignificada no ato performático que Ariano viria denominar de Ilumiara, como celebração e culto dessa mentalidade castanha cariri que se cristalizara em sua obra, em sua compreensão estética de mundo e que se tornaria central nos pródomos e representações do Movimento Armorial.

- Ilumiaras são anfiteatros ou conjuntos-de-lajedos, insculpidos ou pintados há milhares de anos pelos antepassados dos índios Carirys no sertão do Nordeste brasileiro, e que, como "A Pedra do Ingá", na Paraíba, foram lugares de cultos. Por isso, normalmente têm como núcleo uma Itaquatiara, isto é, um Monólito-central, lavrado por baixos-relevos ou decorados por pinturas rupestres. A do Ingá não é pintada, é lavrada numa pedra castanha que até por isso lembra a cerâmica de Brennand. Vista de longe, parece um

12 Discorri sobre o tema no capítulo "Pelo bom comer, pelo bom beber e pelo bom fuder: a comensalidade do catolicismo-sertanejo do Romance d'A Pedra do Reino", publicado no livro A Ilumiara Sob o Sol do Meio-Dia. 
torso de Mulher tatuado pelos letreiros, figuras e sinais. Mais de perto, é Beemot, a Fera terrestre. Sua superfície é coberta por estranhas marcas entalhadas na pedra. Entre elas, uma figura masculina - sacerdote ou Divindade menor, talvez - e que, com uma Esfera entre os pés, parece exercitar-se num passo de jogo ou Dança, ao mesmo tempo em que conduz nas mãos um Vaso de Oferendas. Mas existem, ainda, Candelabros, ou, talvez e mais certo, Pássaros e corolas de Cactos perigosos.

- "Farás para ti um Candelabro de 7 braços" - murmurou Yaari, aludindo à Menorá, o candelabro judaico do Velho Testamento.

- Os candelabros do Ingá têm, normalmente, 9 braços, e não 7 ! - expliquei. - Estão situados junto de Cocares enormes, Lagartos, sóis, luas, sexos, estrelas e Serpentes, formas gravadas não se sabe com que instrumentos rudes e primitivos no Céu opaco, duro, áspero, constelado e chumboso da pele-de-fera da Pedra. Assim, os baixos-relevos insculpidos em sua superfície transformam o Monólito numa grande Escultura que aproveitou e incorporou a forma da Pedra original e que há milhares de anos está ali como homenagem não se sabe a que terrível Deus-Desconhecido". (SUASSUNA, 2008, p.253-254).

Ariano continua sua descrição explicando que a referida Itaquatiara não se encontra sozinha na região, mas com outras se apresenta numa espécie de conjunto arquitetônico, que o autor assemelha àquele construído em Recife por Brennand, numa obra cuja linguagem estaria entre a arquitetura e a escultura na unicidade expressiva de sua Ilumiara, em um conjunto que "termina sendo um Anfiteatro; e a Pedra-Central, um Altar, semelhante a essas Aras estranhas e a esses Tronos brutais de pedra que os Povos antigos, contemporâneos do Velho Testamento, erigiam (...) como implorações de piedade ou como locais de sacrifício" (SUASSUNA, 2008, p.254). Suassuna evoca uma outra discursividade ao Ingá, porque sua leitura ressignifica o monumento de forma a abarcar num único receptáculo uma simbólica ameríndia, outra judaica, além de outras que se viram ligadas numa manifestação significativa que não mais eram aquilo que em origem eram, mas algo novo. Antropofagicamente, o discurso canibal de Ariano tomava a Ilumiara não sob a lógica da predicação, e sim da predação, porque o ajuntamento de rastros não se tratava de tradução de mentalidades, mas a construção doutra mentalidade. Os rastros do que eram ainda podiam ser perceptíveis, contudo a leitura destes não mais eram plurais, não mais evocavam suas existências ou suas permanências, sem que se evocasse a consciência participante que agora lhes era caráter no discurso mitificado da Pedra do Reino, com todos os acordes, cores e sentidos que a Mitologia Tapuia aludia.

Os símbolos da Itaquatiara saíram da rocha deslocados às páginas do Romance d'A Pedra do Reino e, no Folheto LXXX, "O Roteiro do Tesouro", explanou-se o emprego destes nos escudos familiares, armoriais, adotados por Clemente, Samuel e Quaderna. No folheto, o Corregedor questiona ao investigado, Dinis Quaderna, a respeito de suas ligações com Doutor Pedro Gouveia da Câmara Pereira Monteiro, que chegara a Taperoá com a estranha cavalgada 
apresentada no início da Pedra do Reino. Doutor Pedro Gouveia acabara por aliciar o narrador, Clemente e Samuel para que se tornassem partidários do Rapaz-do-Cavalo-Branco, Sinésio, O Alumioso, que fora dado por morto há muitos anos, mas que ressurgira ressurreto, majestoso e divinal na demanda novelosa da Guerra do Reino.

O representante de Sinésio fundara o "Instituto Genealógico e Histórico do Cariri", distribuíra cartas de nobreza e escudos heráldicos, influenciara a vida dos personagens e, segundo Dinis, os acontecimentos da obra e da estranha Desaventura vivida pelo Alumioso. Quaderna afirma ao Corregedor que Pedro Gouveia era homem de astúcias, gentil e cheio de habilidades, a quem muito devia pelo aprendizado de estratégias discursivas que potencializariam seu caráter quengueiro ${ }^{13}$.

Enquanto o Professor Clemente e o Doutor Samuel influenciaram Dinis nos conhecimentos mais literopolíticos, o advogado iria lhe confirmar descobertas de astúcias que Dinis Quaderna fizera sozinho (a esse respeito, a obra As Infâncias de Quaderna traça todo um painel acerca da aprendizagem de Dinis, principalmente no que tange ao tempo em que vivera com os ciganos) e, por outro, por abrir-lhe inúmeras perspectivas novas em chaves e caminhos que iriam lhe pondo ao alcance um número cada vez maior de ardis e defesas.

Com promessas de títulos e posses, Pedro Gouveia seduzira Quaderna e seus pares, repito, outorgando Samuel como Barão do Guarupá e Clemente como Visconde de Caicó. Suas palavras tornaram-se amavios para o trio arregimentado, contudo algo mais lhes foi fornecido: o escudo da família de cada um deles como expressão e representação nobiliárquica. Os escudos possuíam animais heráldicos como característica comum... no de Samuel, uma anta e no de Clemente, uma onça com dois cachorros negros.

Quando chegara a vez de Quaderna e lhes fora apresentada todo o nobiliário da família do narrador, Dinis interpela ao advogado dizendo-lhe que desejava ser consagrado cavaleiro "Sempre desejei ser declarado oficialmente, episcopalmente, regiamente, Cavaleiro, e minha oportunidade é essa: não quero ser Comendador não, quero ser é Cavaleiro!” (SUASSUNA, 2014, p. 670) - e Pedro Gouveia, de pronto, o nomeia como Cavaleiro da Ordem do Templo

\footnotetext{
${ }^{13} \mathrm{O}$ termo "quengo" - e suas derivações - refere-se à recriação no nordeste brasileiro da figura do pícaro, de tradição ibérica. Os nordestinos empregam o termo no sentido de "cabeça", de forma conotativa e denotativa, porque tanto se refere à parte do corpo, quanto àqueles indivíduos espertos, de ideias ágeis, os de "cabeça boa" para seduzir, enganar, para empregar amavios ou armar "presepadas". Em Fortaleza, capital do Ceará, o termo quengueiro se cristalizara de tal forma que passara a ser empregado para denominar uma profissão informal no mercado popular Beco da Poeira. Os quengueiros são aqueles que percorrem os corredores e arredores do mercado em busca de clientes para as bancas de confecção... Eles abordam os possíveis clientes; seduzem a esses numa espécie de pré-venda das mercadorias que encontrarão na banca para a qual o quengueiro trabalha; os guiam pelos corredores para que nenhum outro quengueiro venha a abordar os potenciais clientes no caminho; acompanham a venda e, muitas vezes, auxiliam aos vendedores para que vendam mais, porque seus ganhos são calculados mediante percentagem dessas vendas.
} 
de São Sebastião e lhe outorga como $12^{\circ}$ Conde e $7^{\circ}$ Rei da Pedra do Reino, descrevendo, em resposta a Samuel que lhe perguntara surpreso se Quaderna também seria agraciado com título, seu escudo:

Agora, tem uma coisa: nós chamamos Quaderna comumente, de Quaderna, O Castanho! Não me diga que Quaderna também terá brasão e que no dele existe um Cavalo castanho!

"Existe um Cavalo castanho, sim. Não no escudo, propriamente, mas sim no timbre. O escudo dos Quadernas é esquartelado. No primeiro quartel, há, em campo de ouro, um veado negro vilenado, inscrito numa quaderna de quatro crescentes vermelhos. No segundo, em campo vermelho, cinco flores-de-lis de ouro, postas em santor, ou aspa, e assim os contrários. O timbre é um cavalo castanho, com asas, com as patas dianteiras levantadas e as traseiras pousadas, entre chamas de fogo!"

- "Valha-me Deus, Doutor Pedro!" - disse Samuel. - "Não é possível! Existem, aqui, duas versões sobre a família de Quaderna. Segundo a primeira, Quaderna descende daqueles fanáticos, assassinos e bárbaros, que se coroaram como Reis do Brasil, na Pedra do Reino. Mas o Pai dele, Pedro Justino Quaderna, um raizeiro e parasita dos Garcia-Barrettos, vivia espalhando outra versão, segundo a qual os Quadernas eram descendentes do Rei Dom Dinis de Portugal. Não me diga que o senhor se deu ao trabalho de pesquisar, também, a genealogia de Quaderna!"

- "Pesquisei, sim! Aliás, é meu intento fundar, aqui, um certo Instituto Genealógico e Histórico do Cariri, exatamente para institucionalizar e codificar essas pesquisas, ordinariamente deixadas ao acaso, aqui na Paraíba". (SUASSUNA, 2014, p. 668).

A pedido de Quaderna, seu escudo, além de apresentar os animais heráldicos listados (o cavalo alado e o veado negro), passaria também a apresentar uma onça castanha, conforme apresento abaixo: 
Figura 6: Escudo de Armas de Dom Pedro Dinis Quaderna, $12^{\circ}$ Conde da Pedra do Reino e $7^{\circ}$ Rei do Quinto Império e do Quinto Naipe do Sete-Estrelo do Escorpião

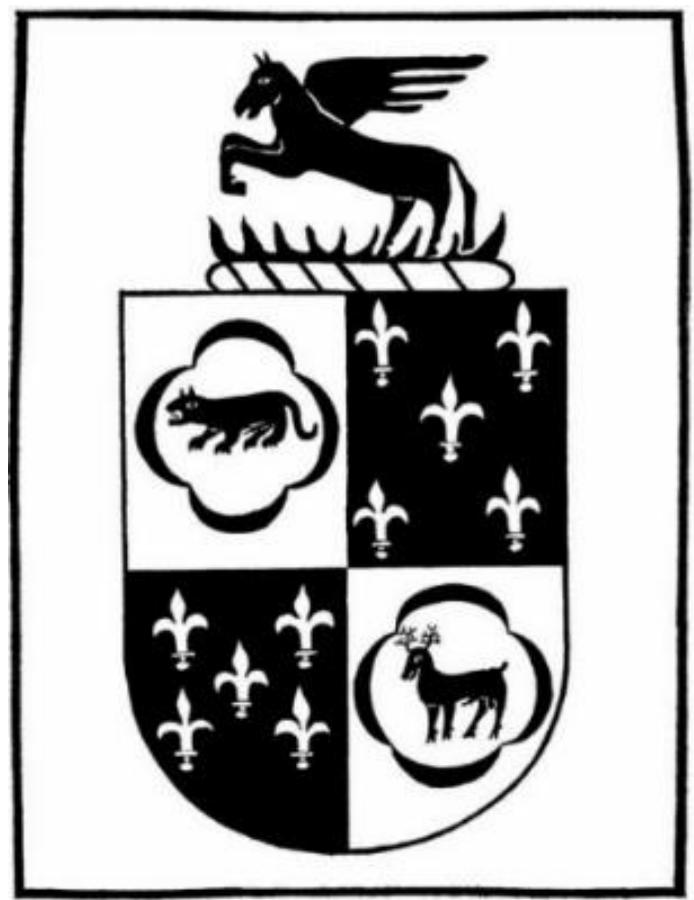

Fonte: SUASSUNA, 2014, p. 671.

Os animais, quando analisados no conjunto da obra de Ariano, são ressignificados nos rastros da refiguração que os coaduna... $\mathrm{O}$ veado remete às origens tapuio-sertanejas e cariris, trazendo o Cacique Suaçuq-Puna, o Veado Negro, como estandarte, metaforicamente referenciando a Albano Cervonegro e, num rastro metonímico, a Suaçuq-Puna evocando uma corruptela a Suassuna. A onça de seu escudo, seguindo o mote apresentado por Idelette Muzart F. dos Santos (1977, p. XVI), seria a demarcação de um outro rastro que ligaria a simbólica da Onça à simbólica do Leopardo e à da Pantera na heráldica medieval europeia relida no romance. A Onça no escudo de Quaderna representaria, então, a Pantera (pan-ther: animal do todo) na obra de Suassuna, porque seria a um só tempo a Onça Parda (o mundo), a Onça Pintada (o Divino), a Onça Negra (a noite e o perigo) e a Onça Caetana (a Morte).

$\mathrm{Na}$ narrativa mitificada, a Ilumiara era local de poder porque o autor elegera os rastros que ressignificariam os sinais rupestres encontrados no Ingá e em outras itaquatiaras como marcadores residuais da presença de uma mentalidade ameríndia, canibalizada em discurso mítico-tapuio... Nesses termos, o escudo heráldico de Quaderna é resíduo, os ferros de marcar gado são resíduos, o alfabeto armorial criado por Suassuna é resíduo, assim como também o seriam suas iluminogravuras, seus romances, seu teatro e sua poesia.

A apropriação desses rastros numa nova construção partilhada, manifestada nas 
xilogravuras ajuntadas no Romance d'A Pedra do Reino e o Príncipe do Sangue do Vai-eVolta, evocam a percepção de que os rastros não mais seriam rastros, mas uma organização cosmológica infundida na maceragem étnica castanha tomada por matéria na identidade narrativa de Ariano Suassuna; assim como também evocariam a percepção de que os resíduos não mais seriam resíduos, mas emblemas armoriais constituintes de uma revolução de perspectivas, de princípios, de leituras e interpretações, de identificação, enfim, do Castelo Literário que Ariano erguera com o espírito castanho do sertão do Brasil.

\section{REFERÊNCIAS}

CARROLL, Lewis. Alice Através do Espelho. Tradução de João Sette Camara; ilustrado por Beatriz Mayumi. Jandiara, SP: Ciranda Cultural, 2020.

CARVALHO, Gilmar de. Madeira matriz. São Paulo: Annablume, 1998.

DERRIDA, J. Gramatologia. Trad. Míriam Chnaiderman e Renato Janine Ribeiro. São Paulo: Ed. Perspectiva, 2008.

DIDIER, Maria Thereza. Emblemas da sagração armorial: Ariano Suassuna e o Movimento Armorial (1970-1976). Recife: Editora da UFPE, 2000.

FONSECA, Fabio. O bestiário medieval na gravura de Gilvan Samico. 2011. 168 f., il. Dissertação (Mestrado em Artes Visuais) - Universidade de Brasília, Brasília, 2011.

LEÃO, Ângela Vaz. A tigre negra: uma iluminogravura de Ariano Suassuna. Scripta (PUCMG), Belo Horizonte, v. 13, p. 13-24, 2003.

. Programa Extra-classe - Ariano Suassuna. Disponível em:

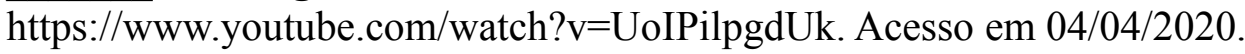

MACHADO, Douglas. O sertão mundo de Suassuna. 2003. Disponível em https://www.youtube.com/watch?v=Xgfu4eDuzE0\&t=2779s. Acesso em 10/04/2016.

NODARI, Alexandre. Transformar-se em nós-outros. Entrevista a Ricardo Machado. In.: IHU On-Line. No 543. Ano XIX. São Leopoldo, RS: USININOS, 21/10/2019.

PEREIRA, Marcos Paulo Torres. Pelo bom comer, pelo bom beber e pelo bom fuder: a comensalidade do catolicismo-sertanejo do Romance d'A Pedra do Reino. In.: PEREIRA, Marcos Paulo Torres \& LIMA, Francisco Wellington Rodrigues (org.). A Ilumiara Sob o Sol do Meio-Dia: estudos sobre a obra de Ariano Suassuna. Macapá: UNIFAP, 2018.

O Cariri em Armadura de Couro: Perspectivismo Ameríndio na Pedra do Reino. In.: LIMA, Francisco Wellington Rodrigues Lima et al. (org.). Matizes de Sempre-viva: residualidade, literatura e cultura. Macapá: UNIFAP, 2020. 
RICOEUR, Paul. Tempo e narrativa. Trad. Constança Marcondes Cesar. Vol. 3. Campinas, SP: Papirus, 1994.

SANTOS, Idelette Muzart Fonseca dos. Em demanda da poética popular: Ariano Suassuna e o Movimento Armorial. 2a ed. Campinas: Editorada Unicamp, 2009.

SPERBER, Suzi Frankl. Ficção e Razão: uma retomada das formas simples. São Paulo: Aderaldo \& Rothschild: Fapesp, 2009.

SUASSUNA, Ariano. Ferros do Cariri: uma heráldica sertaneja. Recife: Guariba, 1974a.

. O Movimento Armorial. Recife: Universidade Federal de Pernambuco, 1974b. . As infâncias de Quaderna. In.: Diário de Pernambuco. 28/11/1976.

Disponível em: http://memoria.bn.br/DocReader/DocReader.aspx?bib=029033 15\&Pesq $=0 \%$ 20veado\%20ne gro\&pagfis=93094 Acesso em: 04/03/2020.

Cadernos de literatura brasileira. São Paulo: Instituto Moreira Sales, 2000.

. Yaari - diálogo sobre a Ilumiara Brennand. In: SUASSUNA, Ariano. Almanaque Armorial. Seleção, organização e prefácio de Carlos Newton Júnior. Rio de Janeiro: José Olympio, 2008.

. Metrópolis - Ariano Suassuna completa 80 anos. Disponível em: http://mais.uol.com.br/view/1xu2xa5tnz3h/metropolis--ariano-suassuna-completa-80anos04026AC0C97346?types=A\&. Acesso em: 04/03/2020.

ZUMTHOR, Paul. A letra e a voz: a literatura medieval. Tradução de Amalio Pinheiro, Jerusa Pires. São Paulo: Companhia das Letras, 1993.

Introdução à Poesia Oral. Tradução de Jerusa Pires Ferreira, Maria Lúcia Diniz Pochat e Maria Inês de Almeida. São Paulo: Hucitec, 1997. 